\title{
Civil-Military Engagement During Public Health Emergencies: A Comparative Analysis of Domestic Responses to COVID-19
}

Samuel T. Boland ( $\sim$ samuel.boland@lshtm.ac.uk)

London School of Hygiene and Tropical Medicine Department of Global Health and Development https://orcid.org/0000-0001-6470-5470

Rob Grace

Brown University

Josiah Kaplan

University of Oxford Department of International Development

\section{Research Article}

Keywords: Civil-military, CMCoord, defence engagement, securitisation, militarisation

Posted Date: August 20th, 2021

DOI: https://doi.org/10.21203/rs.3.rs-801094/v1

License: () (i) This work is licensed under a Creative Commons Attribution 4.0 International License. Read Full License 


\section{Abstract \\ Background}

Despite the central role that domestic militaries regularly play in supporting civilian disease outbreak responses, the dynamics of domestic civil-military engagement (CME) during major health emergencies remain largely under-explored in public health, humanitarian, and security literatures. Previous research has found, furthermore, that existing international and domestic civil-military guidelines hold limited relevance during public health emergencies, including epidemics and pandemics, currently evidenced by the observable lack of coherence and high variance in both international and domestic military approaches to supporting COVID-19 responses worldwide.

\section{Methods}

This article presents a comparative analysis of three of these approaches-in China, the United Kingdom, and the Philippines-and maps these countries' military contributions to the COVID-19 response across a number of domains.

\section{Results}

Analysis of these case studies provides important insights into the ways that CME exists in unacknowledged contexts and forms; how militaries, particularly domestic forces acting as first responders, play an important role in major health crisis contexts; the confusion surrounding how to understand various nonmilitary armed and security actors; and how pandemics, in particular-and other types of largescale health emergencies more broadly-represent a unique domain for CME that tests both the international system and international norms.

\section{Conclusion}

This paper concludes with policy, guidance development, and research recommendations for improved practice for localised CME during public health emergencies.

\section{Introduction}

"We are at war against a vicious and invisible enemy. One that cannot be seen by the naked eye. In this extraordinary war, we are all soldiers". ${ }^{1}$

So said Filipino president Rodrigo Duterte on March 16, 2020 in a press conference discussing the country's response to the COVID-19 pandemic. In China, the COVID-19 response had been framed as a "people's war". ${ }^{2}$ In the United States, President Donald Trump referred to himself as a "wartime president". ${ }^{3}$ On the one hand, the "war metaphor" is rhetoric wielded to demonstrate a firm political commitment to confronting the pandemic. ${ }^{4}$ On the other hand, the discourse of war has complemented and reinforced the robust array of functions that national militaries-as well as police, paramilitary militias, and gendarme-across the globe have served in governments' efforts to manage the global COVID-19 outbreak. In every aspect of responding to the pandemic-coordination, planning, logistics, direct medical care, research on vaccines and treatments, regulating and enforcing mobility restrictions-militaries and other armed actors have played an important role.

What does the COVID-19 experience mean for domestic civil-military engagement (CME) during public health emergencies? Various sets of principles-notably those of the United Nations Office for the Coordination of Humanitarian Affairs (UN OCHA)-exist for bounding the role that international military forces play in supporting civilian actors during humanitarian responses activities. ${ }^{5}$ These principles aim to maintain overall civilian direction of the response, and ensure that international military contributions are deployed in concordance with established humanitarian principles and as a 'last resort'. ${ }^{6}$ But in the case of domestic military support within a country's own public health emergency response, these principles do not necessarily apply.

In the context of COVID-19, domestic militaries have served as first responders. As countries' own national civilian public health capacities were quickly overwhelmed by the pandemic, operational military support was redirected toward logistical and medical support as part of the COVID-19 response. Additionally, defense industries and science capabilities typically reserved for domestic national security priorities were redirected toward surveillance, research, and production of personal protective equipment (PPE). A fair amount of policy attention has been directed toward international armed forces operating amidst humanitarian crises. However, public health emergencies have not been linked to this field of analysis and thinking. Moreover, the complicated dynamics of health and humanitarian responders engaging with domestic militaries has been under-examined as well. In this sense, the COVID19 response-and other types of largescale public health emergencies more broadly-falls within a nexus between two crucial gaps in research, as well as policy analysis and thinking, the first being largescale health emergencies as a distinct type of response context in which civilian and military responders interact, the second being how civilian responders can shield themselves from politicization while engaging, coordinating, and collaborating with domestic (as opposed to international) military actors. As this article later explains, the COVID-19 response reflects many of the same dynamics discernible in the field of humanitarian-military relations. Conversely, the COVID-19 response yields lessons from which the broader field of humanitarian-military relations can learn. Moreover, many of the very same military actors deployed domestically during the COVID-19 response have been, or in the future likely will be, deployed internationally in the context of other types of humanitarian responses, such as natural disasters. The same holds true for certain civilian responders who have worked domestically on the COVID-19 response. Hence, there is discernible value in analytical cross-pollination between, on the one hand, the broader field of humanitarian-military relations, and on the other hand, the CME dynamics at play during largescale public health emergencies. 
The pandemic has, ultimately, offered the largest natural experiment of comparative national responses to a shared public health crisis in modern history. From a CME perspective, what insights can a comparison of individual country's COVID-19 experiences tell us about the how military and civilian actors engage in such contexts? And what lessons can be drawn for future policy and practice?

\section{Methods}

This article seeks to examine both questions through a comparative analysis of CME in three illustrative country case-studies: China, the United Kingdom (UK), and the Philippines.

First a broad overview of the field of CME during large-scale health emergencies is provided, highlighting the state of research in this area and the linkages with the broader field of humanitarian-military relations. Following this, the three case studies are elaborated-based on a desk review of open-source material -with a focus on CME in response to COVID-19. The third section discusses several themes that arise from an analysis of the case studies. Finally, concluding remarks and recommendations for policy and guidance development are offered, as are considerations regarding avenues for further research relevant to improved understanding of CME in future public health emergencies.

\section{Background}

CME during large-scale health emergencies represents a small but emerging area of research and practice. ${ }^{6}$ Military actors have played a substantial role in myriad natural responses to disasters triggered by natural hazards, both domestically and-especially since the 1990s-as part of international missions. Examples include Hurricane Mitch in Central America in 1998, the 2004 Indian Ocean tsunami, the 2010 Haiti earthquake, the 2010 floods in Pakistan, Typhoon Haiyan in the Philippines in 2013, and the 2015 Nepal earthquake. Militaries have also been involved in stabilisation and counter-terrorism activities that blur lines between military and humanitarian objectives, such as the U.S.-led military operations in Afghanistan and Iraq; forced displacement crises including in Kurdistan in 1991, Kosovo in 1999, and Bangladesh in the context of the Rohingya refugee crisis; and public health emergencies, such as the 2013-2016 Ebola outbreak in West Africa and the 2018-2020 Kivu Epidemic in the Democratic Republic of the Congo.

International guidance for good practice regarding humanitarian civil-military coordination (CMCoord) includes the Oslo Guidelines (applicable in "natural disasters"), the Military and Civil Defence Assets (MCDA) Guidelines (relevant during complex emergencies), the 2004 Inter-Agency Standing Committee (IASC) reference paper (also relevant during complex emergencies), and various agency-specific guidelines. ${ }^{5}$ Key CMCoord principles aim to ensure the civilian, principled nature of humanitarian response when international military assets are used. Various analysts have, at the same time, articulated grave concerns about blurred lines between humanitarian and military objectives, as well as the importance of humanitarian principles in navigating these difficulties. ${ }^{7}$

Despite this growing body of research on humanitarian-military relations, significant empirical gaps remain in basic areas in this field. First, the literature has only just started to explore the full range of $\mathrm{CME}$-such as innovation and knowledge exchange, for example-that fall beyond operational coordination. ${ }^{8}$ An underexplored challenge is how to manage CME across a wide range of issue areas, including operational coordination, humanitarian access and security, and humanitarian protection. ${ }^{9}$ In complex emergencies, these challenges can be particularly acute, as humanitarians grapple with managing humanitarian notification systems and questions surrounding the appropriate use of armed escorts in insecure environments. ${ }^{9}$ Second, scarce scholarship exists that probes the actual dynamics and impact of $\mathrm{CME}$, including the uptake (or not) of existing guidelines, practices adopted for managing $\mathrm{CME}$ effectively, the factors that shape local perceptions, and considerations regarding how to evaluate whether CME has been successful or not. ${ }^{10,11}$

These literature gaps are particularly acute for CME in contexts of large-scale health emergencies, including pandemics. What are the different ways CME manifests in epidemic or pandemic contexts? What are the impacts of these interactions? Scholars have just begun exploring these questions (e.g. Horne and Boland, 2020). ${ }^{12}$ Moreover, there is a lack of CME guidelines specific to large-scale health emergencies as a distinct form of crisis. ${ }^{5} \mathrm{~A}$ disease outbreak also often brings militaries into a policing function-namely, to regulate quarantines or lockdowns-but there have not been connections made with the broader literature on this issue, an especially crucial gap given the risks of bringing militaries into roles that fall outside their traditional areas of competence (e.g. Dunlap, 1999). ${ }^{13}$ This research gap persists even though military policing in the context of disease outbreaks is a role that militaries have played for centuries. ${ }^{14}$ In the COVID-19 response specifically, the emerging literature on CME has highlighted familiar challenges from the field of humanitarian-military relations, including the lack of adequate collaboration and coordination between military and civilian health and humanitarian responders, human rights concerns stemming from militaries' law-and-order function, and the challenge for the military of engaging in a health response while still retaining readiness for its more traditional functions. ${ }^{15}$ The literature has also begun to examine the different roles militaries have played, ${ }^{15-17}$ as well as lessons learned in leadership and coordination from past experiences. ${ }^{18-20}$

However, this literature has not delved into various non-traditional aspects of humanitarian-military interaction-for example, knowledge-production and sharing-that can be important aspects of military engagement in health emergencies, as this article later examines. Additionally, a notable aspect of COVID19 responses has been intensive involvement of national militaries or other local security actors. Although there have been some examples of international military deployments to respond to COVID-19, ${ }^{21}$ the predominantly local nature of responses highlights a particular gap in existing research and guidance, which focuses on the use of international military assets and does not delve into comparative analysis of domestic issues that arise during large-scale public health emergencies. The illustrative case studies below, and the analysis that follows, aim to highlight and start to fill this gap.

\section{Results}

This section presents three case studies to illustrate some of the commonalities and differences in CME during COVID-19. These empirical observations are drawn from China, the UK, and the Philippines. In each of these contexts, militaries played a significant, wide-ranging role in the COVID-19 response.

Page $3 / 16$ 
Additionally, these contexts constitute a range in terms of the role that CMCoord principles have played in framing coordination between civilian and military responders. At one end of the spectrum is China, where the role of CMCoord principles in the response has been non-existent. In the middle is the UK, where principles of CMCoord (in particular, the principle of 'last resort') have been formally integrated into the domestic governmental response architecture. At the other extreme is the Philippines, which is a humanitarian response context with a significant international humanitarian presence and where $\mathrm{CMCoord}$ principles have been explicitly used to frame humanitarians' engagements with local military actors.

China

Overview

The world's first cases of COVID-19 were identified in Wuhan, Hubei Province during early December 2020. In response, China quickly positioned the People's Liberation Army (PLA) at the centre of a national response defined by close, highly-visible CME. ${ }^{22}$ A limited body of publicly available data and analysis makes detailed assessment of China's experience in coordinating military and civilian components of its COVID-19 response challenging, especially as related to a critical evaluation of topics such as human rights abuses. Available evidence suggests that, on the whole, the PLA's role in helping manage the pandemic has been largely well-coordinated and effective. However, the early response featured some initial challenges in the interoperability of China's discrete emergency management and national defence systems, and technical challenges were also confronted. ${ }^{23}$ Widespread human rights concerns have also been voiced related to China's approach to enforcing lockdowns resulting in inadequate access to food and healthcare. ${ }^{24}$ Looking forward, COVID-19 has also proven to be a critical test of the PLA's recent modernisation efforts and the further centralisation of China's future approaches to public health emergency response. ${ }^{25}$

Governance structures

China places CME at the centre of a whole-of-government approach to national defence mobilisation. ${ }^{26}$ Article 4 of China's National Mobilization Law, in particular, states that "national defense mobilization shall stick to the policies of combining civil with military, combining peacetime production with wartime production and embedding military in civilian (sic)". ${ }^{27}$ This relationship is further supported by the PLA's central strategic doctrine of 'military-civil fusion'. ${ }^{23}$ In the context of COVID-19, China's approach mobilised all available resources and personnel across military, reserve, and militia forces in addition to civilian enterprises, all framed within a strategic goal of "putting in place a defence line across the whole of society and relying on the people to win the battle" against COVID-19. ${ }^{28}$

To this end, the country's massive nationwide campaigns for pandemic prevention and control activities has been overseen by China's Party Central Committee (PCC)'s Central Military Commission (CMC). ${ }^{29}$ The CMC has, in turn, overseen deployment of the PLA's reserve forces, militia, and province-level military commands, hospitals and medical programs. ${ }^{30}$ This control has been extended and augmented through a parallel structure of provincial, district, country, and municipal national defence mobilisation commissions designed to support local efforts. ${ }^{25}$

Forms of military contributions to the COVID-19 response

The PLA's first-and most highly visible-role was in providing emergency support to front-line treatment within Wuhan in the outbreak's first wave through the deployment of several thousand military health workers in January, $2020 .{ }^{28}$ By early February, these same personnel began receiving patients at two civilian health centres, and by mid-February the PLA had built and staffed two large COVID-19 field hospitals that would later admit over 7,000 COVID-19 patients. ${ }^{31,32}$

The newly-formed PLA Joint Logistics Support Force (PLA-JLSF) took responsibility for deploying most units and medical services across five theatre commands, with local theatre commands overseeing their own joint logistics and medical support centres. ${ }^{33}$ As the first real-world test of the PLA-JLSF since its establishment in 2016, Chinese military logistics proved effective in rapidly deploying hundreds of thousands of military medical personnel and militia to outbreak locations throughout China, the region, and to global allies. ${ }^{25}$ The PLA's cadre of specialised military healthcare personnel provided direct clinical care in military-established field hospitals, monitored the outbreak, and oversaw distribution of PPE and other supplies.

The Chinese defence industry also produced huge volumes of PPE and medical supplies and reinforced supply chains. They also contributed to international PPE exports via World Food Programme (WFP) and World Health Organisation (WHO) mechanisms. ${ }^{34}$ More than forty medical companies were ordered under military mobilisation directives to expand their production with support from military personnel, ${ }^{25}$ as well as tech companies manufactured and distributed autonomous robotic systems for unmanned distribution, diagnosis, and disinfection work. ${ }^{35,36}$

The collective scale of PLA logistics support during COVID-19 is hard to overstate, especially when the militia are also considered: potentially millions were deployed across China. ${ }^{25}$ Chinese militia-which function as an auxiliary reserve force for the PLA-supported the response through logistics, distribution, and the communication of public health messaging in local communities. Indeed, the familiarity of militia units with local communities proved advantageous in leveraging grassroots engagement, both for public health messaging and maintaining a narrative of social stability in face of unrest. ${ }^{25,37}$

The PLA also contributed to COVID-19 research and surveillance through its medical universities and a specialised medical centre run by the PLA Strategic Support Force. PLA medical research benefited from recent modernisation reforms across military medical institutions for improved military readiness, including increased recruitment of civilian scientists, international exchanges with military and civilian medical practitioners, and greater investment in research facilities. This has also included some controversial approaches to technology transfer, including exploitation of scientific cooperation arrangements for military or dual-use applications. ${ }^{25}$ Further, PLA scientists helped to develop the world's first COVID-19 restricted-use-approved vaccine with peer-reviewed results published as early as July, 2020. ${ }^{38}$ 
In short, the PLA has supported a wide range of CME knowledge and research support functions during COVID-19. More broadly, PLA personnel also leveraged learned experience acquired through previous pandemic response missions, which was worked into both support to civilian authorities and prevention and control measures and training within PLA ranks. The PLA began the response with a recent history of highly relevant experiences in medical and humanitarian CME acquired from prior missions. Therein, PLA medical cadres' response showed significant maturation in CME doctrine, good practices, and operational effectiveness relative to past responses, particularly its response to the SARS pandemic (2002-2004), Ebola in West Africa (2013-2016), earthquakes in Sichuan (2008) and Yushu (2010), and the Indian Ocean Tsunami (2004). ${ }^{25}$

Finally, China actively engaged in international military assistance to regional and international COVID-19 response efforts. The PLA provided vaccines, test kits, and PPE to a wide range of other countries throughout Asia and South Asia, the Middle East, Europe, and South America. ${ }^{25,37}$ Beyond material supplies, PLA military medical personnel also shared expertise acquired in recent pandemic missions, particularly China's SARs and Ebola responses. In Sierra Leone, for example, the Chinese Military Medical Expert Group-already familiarised with the context from the West Africa Ebola response-supported Sierra Leone health authorities with their COVID-19 response. ${ }^{39}$

United Kingdom

Overview

The British military's contributions to the COVID-19 response arguably began before the pandemic, through ongoing military medical support to the National Health Service (NHS), scientific contributions through the Ministry of Defence (MoD) Defence Science and Technology Laboratory (Dstl), participation in training exercises and civil-military workshops, and a history of support to local councils' coordination and planning bodies during major incidents. ${ }^{40}$ COVID19-related support began in January, 2020, when British citizens in Wuhan were repatriated via a military facility. ${ }^{41}$

This marked the first in a rapidly growing number of support streams as the crisis unfolded. Significant and varied assistance has been activated through the Military Aid to Civil Authorities (MACA) policy across myriad domains. In mid-March 2020, this support was formalised under two interrelated military operations (for domestic and international roles, respectively) and included formation of the 10,000-later-23,000-strong-COVID-19 Support Force (CSF) of standby military personnel, many of whom had been recalled from cancelled international training programmes. ${ }^{42}$ Standby personnel numbers have fluctuated with the outbreak. As of March, 2021, 14,000 military personnel remain on standby with 2,600 actively engaged in support to 56 separate MACA requests. ${ }^{43}$ This represents the "biggest ever homeland military operation in peacetime". ${ }^{44}$

Governance structures

In 1964, the UK introduced the MACA framework as well-defined and structured provision through which civilian governmental departments can request domestic military support. ${ }^{45}$ These requests must be a 'last resort', when support is required that cannot be provided by a public or private civilian agency because the capability does not exist or cannot be deployed with sufficient scale or speed. It must also be considered too expensive to develop this skill in a civilian agency. ${ }^{46}$ Military personnel responding to a MACA request fall under both civilian and military law and therefore have "no powers over and above those of ordinary citizens... [and] have the same personal duty as anyone else to abide by the law at all times". ${ }^{46}$ MACA is invoked with some frequency in the UK for issues ranging from flood response to terrorism to strike-breaking. ${ }^{47}$ Therein, UK governance surrounding military support to civilian authorities was both well established and frequently exercised prior to the COVID-19 pandemic.

Forms of military contributions to the COVID-19 response

The British military's contributions to the COVID-19 response span a wide array of domains, though notably this excludes law enforcement and maintenance of public order.

The military is actively involved in the production of 'soft' knowledge, including the countering of COVID-19 disinformation by anti-propaganda and psychological warfare experts. Other forms of soft knowledge include assistance between military medics-trained for and experienced in rapid-onset trauma and mass casualty events-and civilian doctors in the NHS, academic knowledge exchange, or CME and contact workshops. ${ }^{48}$ Contributions to hard sciences and research are also myriad. Notably, two MoD-funded Dstl biosafety level 4 laboratories research dangerous pathogens including COVID-19 and provide unique and unprecedented laboratory capabilities and training; some Dstl staff were seconded to Public Health England (PHE). ${ }^{49}$ Further support includes $3 \mathrm{D}$ printing and production of PPE to testing the NHS contact tracing app in military bases. ${ }^{50,51}$

Support to logistics and the provision of a large, disciplined, and flexible workforce to back-stop overwhelmed civilian services is substantial. Logistically, this includes domestic and international airlift including repatriations, medical evacuations, and medically critical supply chain (the latter also done on behalf of the WHO and WFP as requested by UN OCHA); manufacturing of PPE and disinfectants; repurposing of military sites to open up additional patient beds and morgue spaces; and the construction (and operation) of testing sites, vaccination centres, and field hospitals. ${ }^{42,43,52}$ Additional support from the at-times 23,000-strong CSF has included driving oxygen tanks and ambulances; ${ }^{53,54}$ medical secondments to the NHS (indeed, "very few defence medics are not currently deployed or working in the NHS"), ${ }^{55}$ and personnel to support testing and vaccine sites, contact tracing call centres, and NHS supply depots.

Support to coordination and planning is largely actioned through 'local resilience forums', otherwise civilian inter-agency bodies at the local level which are mandated to plan and execute responses to events like flooding. For COVID-19, military planners and liaison officers are embedded in these forums to provide support, expertise, and to serve as a liaison for the request of further military assets. ${ }^{55}$ The military also provides a "philosophy of planning" which contributes 
to coordination and planning in diffuse but important ways. ${ }^{52}$ Further contributions includes deployment of NATO's Allied Rapid Reaction Corps to support planning in London, and military crisis planners to backstop overwhelmed NHS trusts. ${ }^{56,57}$

The British military's contributions to politics and diplomacy in the COVID-19 response are diffuse and as-yet somewhat undefined in the literature, but their clear, present, and substantial role certainly demonstrates-at least optically-an unambiguous reflection of the emergency and crisis context to the general public, which is reinforced with celebratory discourse from government sources despite how it also evidences a lack of resilience amongst the government's civilian institutions even though the UK is a high-income and stable liberal democracy. ${ }^{58}$ Examples of diplomatic efforts include international support such as the delivery of medical aid to Ghana, provision of military planners and other personnel to the Cayman Islands and Turks and Caicos, and various support streams to British Overseas Territories. ${ }^{59}$

The Philippines

Overview

The Philippine government was initially slow to in their response to COVID-19. However, after community transmission grew in March 2020, President Duterte shifted from downplaying the virus to embracing militarised rhetoric in order to publicly demonstrate a commitment to defeating COVID-19. ${ }^{60}$ By April, President Duterte had declared various broad quarantines and a country-wide "State of Calamity", ${ }^{61}$ banned travel to and from Manila, and was granted additional emergency powers. ${ }^{62}$ The Defence Secretary was placed in charge of the newly-formed COVID-19 National Task Force (NTP). ${ }^{63}$

State of emergency measures also gave the Secretary of Health the ability to request support from the Armed Forces of the Philippines (AFP) and the Philippine National Police (PNP), which were "directed to undertake all necessary measures to ensure peace and order in affected areas". ${ }^{64,65}$ Subsequentlyboth by request and requirement-the AFP played a significant and varied role in the COVID-19 response.

Governance structures

The Philippines is prone to disasters triggered by natural hazards, and the AFP has long played a role in response efforts. Governmental coordination entities include the Inter-Agency Technical Working Group for the Management of Emerging Infectious Diseases (IATF-EID) as well as the Office of Civil Defense, which is the Secretariat of the National Disaster Risk Reduction and Management Council (NDRRMC) and is responsible for coordinating the use of military assets in disaster response. ${ }^{66}$ However, the COVID-19 National Task Force was given responsibility to lead the government's response-including militarily-through the emergency powers outlined above. Coordination within the COVID-19 National Task Force has been necessary between its civilian and military entities as well as with international humanitarian organisations participant in the national disaster management cluster system. ${ }^{66}$ This is further complicated by a new antiterrorism law that was adopted in summer 2020 that criminalises "material support" for people designated as terrorists, a provision in the that could conceivably encompass certain types of COVID-19 programming. ${ }^{67,68}$

Forms of military contributions to the COVID-19 response

Tens of thousands of AFP personnel have been deployed as part of the COVID-19 response effort. ${ }^{69}$ As noted, the AFP has extensive past experience and a defined mission supporting responses to disasters triggered by natural hazards and subsequent reconstruction, and possesses unique capabilities relative to civilian actors such as the size of its labour force, its airlift and heavy transport capabilities, and its ability to access hard-to-reach locations throughout the country. ${ }^{61}$ Therein, to many Filipinos, the AFP's deployment during the COVID-19 is familiar. ${ }^{61}$ Nevertheless, COVID-19 still represents new territory for the country's tradition of CME which demand further elaboration.

On a large scale, the AFP has transported medical and laboratory equipment and supplies, personnel, and food assistance. ${ }^{69}$ It has also deployed thousands of military medical personnel to treatment and quarantine centres, dropped COVID-19 information leaflets from aircraft, and supported the Office of Civil Defence through voluntary donations of military salaries. ${ }^{70,71}$

The AFP and PNP have played a significant security, policing, and enforcement role in the response. This role has entailed checkpoint monitoring-including mandatory health screenings-and aerial monitoring. ${ }^{60,69,71,72}$ Despite the mandate to implement and enforce lockdowns, initially there was little-to-no guidance (public or otherwise) for how to do this while ensuring adherence to human rights, and this aspect of the response has therefore attracted fierce criticism from local and international actors. ${ }^{73}$ Indeed, the AFP and PNP-with a blurred distinction between them in terms of their roles and responsibilities, as well as a lack of visible distinction in terms of uniforms-has been widely reported to be responsible for killings, mass arrests, and detainee abuse adjacent to these roles (e.g. Human Rights Watch, 2020 and UN News, 2020). ${ }^{74,75}$

Retired military personnel who had transitioned into high-level civilian government leadership positions have played a significant role in implementing the Philippines' National Action Plan. The COVID-19 National Task Force is chaired and vice-chaired by ex-military personnel; the latter, a former AFP chief of staff, also leads the Department. of the Interior and Local Government; another former AFP chief of staff is currently the 'COVID-19 policy chief implementer'; and yet a third former AFP chief of staff is the 'COVID-19 Response Overseer' as well as being the Environment Secretary. ${ }^{76,77}$ Criticism herein has included lack of technical expertise and suggestions that medical experts should play a central role in leading the response. ${ }^{61,78}$

Overall, the military has played a very visible role in the Philippine government's COVID-19 response. President Duterte has also employed wartime rhetoric and imagery, appearing in public with uniformed military personnel. This poses a challenge for humanitarian organisations operating in the Philippines and aiming to maintain their impartiality, neutrality, and independence. The Humanitarian Country Team has directly translated international CMCoord guiding principles into this domestic context to inform how humanitarian organisations in this context should engage with the AFP. Operational Guidance published by the 
Philippines Humanitarian Country Team-which is akin to advice as it is not binding or enforceable-includes provisions outlining how humanitarian engagement with the military during COVID-19 should not compromise humanitarian principles or place vulnerable populations at risk, and how military contributions must remain a last resort. ${ }^{79}$ This element is particularly pertinent given the ongoing armed conflict in Philippines: the government and the Communist Party of the Philippines (CPP) both unilaterally announced a ceasefire in the pandemic's early weeks, but the ceasefire did not hold. ${ }^{80,81}$ Violence in Mindanao has continued over the course of the COVID-19 outbreak. ${ }^{82}$ There has also been ongoing violence between the government and Islamic Stateaffiliated groups, including bombings in Jolo city in August $2020 .{ }^{83}$ In the country's conflict-affected areas, military involvement in the COVID-19 response gives rise to concerns that civilians could become collateral damage should anti-government militants seek to strike targets where military actors are present. $^{84}$

\section{Discussion}

CME exists in unacknowledged contexts and forms

Analyses of military contributions to civilian humanitarian responses have generally focused on describing and problematising more easily quantifiable forms of support, particularly logistics, troops, and materiel. Militaries are also recognised, as a secondary contribution, for their coordination and planning capabilities, as well as for the provision of security, policing, and enforcement in kinetic or complex emergencies. In turn, principle-based guidance surrounding CME and best-practice-at both international and domestic levels, and as specific to individual humanitarian agencies-focuses predominantly on marking boundaries and setting parameters for these specific areas of engagement. ${ }^{5}$

In practice, however, there is a much wider range of modalities in which militaries and civilians interact and exchange support during emergencies. This point is clearly evidenced during the COVID-19 response worldwide as militaries have engaged in these activities across the full range of operational contexts from complex emergencies to stable democracies.

In particular, pandemics and other health emergencies rely on collaborative approaches to surveillance, data, and scientific research. During these whole-ofsociety crises, knowledge exchange-including both formalised transfer of health intelligence, and the 'soft' diffusion of expertise and innovation, between military and civilian practitioners-represents a particularly important but under-acknowledged domain of CME. ${ }^{8,12}$ As an active sphere of CME, military-civilian knowledge exchange should presumably be subject to the same principle-based scrutiny as more explicit, quantifiable types of interaction, such as logistics and material support.

The preceding case studies evidence how these military contributions to the wider public health evidence base-including surveillance and scientific research around vaccine development, PPE product innovation, and codification of good clinical practices, among other contributions-have been critical to COVID-19 responses in each country. In China, much of the COVID-19 CME occurred outside of direct operational support, instead taking place in contexts of research and innovation, such as through the PLA military medical establishment's active leadership role in research and vaccine development. These contributions to hard and soft sciences were echoed in the UK, such as through extensive scientific work, research, and development at the Dstl, to trialling civilian contact tracing technologies in military bases, to diffusing a culture of coordination and planning and participation in civil-military learning and workshops. This knowledge exchange existed before COVID-19, as was the case in China, but has been reinforced throughout the pandemic as both a resource to be utilised and a tool-in some ways one of CME integration rather than division-to be further developed. In the Philippines, the military has likewise accrued extensive experience as a capable response partner and deployed this expertise widely as part of the COVID-19 response.

CME through knowledge exchange, rather than material contributions, can also be seen in the adaptation of concepts and models of military planning and coordination into all three country's COVID-19 response efforts. Applying structures explicitly from military organisations to civilian practice is common to national emergency response models and pre-dates COVID-19. Nonetheless, the impact of this conceptual diffusion from military to civilian spheres in shaping the character of civilian humanitarian and health response activities deserves greater critical engagement within the study of CME. Here, critical scholarship on analogous issues may offer a useful point of reference. ${ }^{85}$

Current frameworks for understanding both domestic and international CME primarily focus on functional, operational areas of intersection between civilian and military responders. This framing, we argue, overly-constraints the wide spectrum of ways in which we can observe such engagement during crises that are as complex and multi-dimensional as a global pandemic. The implication is that a more expansive framework for CME is needed, one that considers the domains of soft knowledge diffusion, hard sciences and research, and knowledge exchange, in addition to more typically assessed contributions to logistics and personnel, coordination and planning, and security, policing, and enforcement, among others.

In public health and humanitarian emergencies, domestic militaries are often 'first responders' rather than a 'last resort'

COVID-19 responses in all three countries feature military actors who have been asked to perform various and often crucial support functions as a provider of 'first', rather than 'last', resort. The concept of international militaries as providers of 'last resort' during humanitarian emergencies is foundational to humanitarian principle-based CMCoord guidance, although it is intended to apply only to international MCDA (as in the Oslo and MCDA guidelines, for example). ${ }^{86}$ In theory, the demarcation between 'last resort' international military support, versus a country's often 'first resort' deployment of its own military in disaster response, is relatively clear in policy language. In practice, however, many humanitarian organisations' own guidance on engagement with national militaries is heavily informed by the principle of such engagement only as a 'last resort' (as in the Philippines COVID-19 response), and many countries also hold principle-based constraints bounding military contributions to civilian relief efforts (as the UK case demonstrates).

This ambiguity is illustrated by the diversity of attitudes towards military contributions in all three countries, each of which offer a comparative reference point for differing institutional and cultural relationships towards CME which underlay their COVID-19 responses. In China, the military was both seen to be and

Page 7/16 
explicitly acknowledged as the country's 'first responder' throughout the course of the pandemic. While civilian authorities initially led the response in Wuhan during the outbreak's initial days, the military was quickly directed to assume responsibility as a result of local civilian administrative dysfunctions. This close CME as a means of first resort has been long-established in China's existing CME doctrine and strategic national defence mobilisation architecture, which was echoed in the UK where the military played a central role in supporting civilian health workers and local planners. As in China, the UK military was formally brought into the response from the very beginning of the country's outbreak through pre-established doctrinal mechanisms which facilitate and indeed encourage CME during domestic crisis response. Importantly, 'last resort' is a listed requirement for these MACA requests under UK doctrine; but at the same time, other criteria (such as affordability considerations) mean that functionally military support is actioned quickly and early, especially with the surfeit of capacity and personnel resulting from cancelled international exercises. In the Philippines, the rapidity with which the military was folded into the response was grounded in its well-established tradition of acting as a key stakeholder in past and ongoing responses to disasters triggered by natural hazards, as well as the formalised role of the military in the national disaster response coordination architecture.

In the context of China, the authorities appear to have made an early assessment of perceived limitations in the planning, command and control capacity of Wuhan's civilian public health system as a justification for shifting towards military-led response. A particularly intriguing question-albeit one that is difficult to answer in the still-evolving COVID-19 pandemic that-is the impact this modality will have on planning assumptions around civilian agencies' role in future pandemic responses, as well as responses to other types of largescale health crises, going forward. Much will rest on the degree with which China's lessonslearning from this process emphasise the PLA's contributions as having augmented, versus having displaced or made redundant, traditional civilian leadership.

The Chinese, UK, and Philippine experiences during COVID-19 suggest that domestic-led responses to public health emergencies-particularly at the scale of an epidemic or pandemic-call for reconsidering foundational expectations around CME. Many countries across the world claim long-established traditions of employing military support as means of first resort in domestic and regional responses. As the pandemic's scale forced regular state providers of international aid to prioritise resources for their own domestic responses, governments deployed their own or other's military assistance under existing domestic legal frameworks.

Existing literature and guidance on humanitarian-military relations has been largely centred around contexts of 'natural disasters' and complex emergencies, with a focus on engagement with international militaries, and a reference point to the foundational principles of humanitarian practice (such as humanity, impartiality, independence, and neutrality). There is a need, however, for further critical analysis of how applicable such premises and assumptions are to public health emergencies as a specific form of disaster-which, while sharing many similarities to humanitarian crises, are more consistently defined by domestic-led responses that entail state civilian leadership, robust military involvement, and sometimes a subordinate role for civil society. ${ }^{5}$

All three contexts-China, UK, and the Philippines-are distinct from one another. The Philippines, even before COVID-19, was an ongoing humanitarian response context in which responders have directly referenced $\mathrm{CMCoord} \mathrm{principles.} \mathrm{China} \mathrm{and} \mathrm{the} \mathrm{UK,} \mathrm{where} \mathrm{there} \mathrm{is} \mathrm{no} \mathrm{largescale} \mathrm{humanitarian} \mathrm{presence,}$ differ from the Philippines in this regard, although in the UK (and not in China), principles of CMCoord (including the principle of last resort) are embedded in the domestic response architecture and have informed governmental decisions about incorporating military actors into the response. Nevertheless, in all three contexts examined in this article, civilian actors have navigated a response context that is politicized and securitized to a certain degree. In this sense, civilian responders in all three contexts have grappled with the fundamental challenge that humanitarian principles, and CMCoord principles more specifically, were designed to mitigate: how to maintain the overall apolitical nature of a largescale disaster response. The key question that these contexts evoke is how response actors in a domestic setting can navigate this same overarching tension.

The political environment of CME

Humanitarian civil-military debates often focus on technical issues decoupled from recognition or analysis of the broader political environment in which militaries are deployed and used for supporting civilian response. Much of the concern around preserving civilian humanitarian independence stems from recognition that militaries-as extensions of state power-come to emergencies with their own political agendas that may not conform to humanitarian principles. The COVID-19 crisis illustrates the complexity and diversity of how military contributions to the wider public health response played out in practice, set within the context of wider political considerations. The preceding analysis provided examples of this point from three countries; the fact that nearly every country in the world confronted similar questions suggests that these challenges speak to a much wider potential empirical base of comparison.

In China, for instance, COVID-19 has highlighted the position of PLA medical institutions as key agents of Chinese health diplomacy and military diplomacy. China's Secretary of the Central Political and Legal Affairs Commission Guo Shengkun put it plainly: "during the pandemic, we seized important achievements in a short time and have posed a great contrast between 'China's orderliness' and 'the West's chaos"' ${ }^{87}$ This suggests an insight into the motivating factors driving militarisation of an ostensibly civilian emergency response domain and underscores the political environment in which any CME activity inherently takes place.

It is further relevant that, in the Chinese context, the pandemic was explicitly described in terms of military conflict, and that this framing in turn structured expectations for the response in terms of military approaches, even blurring or erasing conceptual distinctions between 'military' and 'civilian'. China Military Online, for instance, described COVID-19 and the response to it as "nothing short of a war" ${ }^{88}$ Similarly, in the Philippines, President Duterte used the military and their role in COVID-19 as a rhetorical device to support the projection of government control and authority. Here, the UK again offers a counterexample, where the role of the military has certainly been celebrated but has not necessarily been elevated as a central tenet of the domestic response. This perhaps contributes to and evidences different political calculus playing out in upper middle-income autocracy, lower-middle income populist democracy, and highincome liberal democracy, in China, the Philippines, and the UK, respectively. 
These case studies suggest analysis of CME should not be limited to a technical or indeed operational discussion: it must feature complementary political contextualisation and analysis as a matter of course. Contributions made by militaries and military personnel to humanitarian and health responses are, by definition, highly political, with priorities shaped by the political environment of military actors, states, as well as domestic and international civil society actors, and should be recognised as such. Indeed, the discourse surrounding COVID-19 represents a rhetorical space into which military concepts and mental models are diffused. These models, in turn, shape the nature of civilian humanitarian response: for example, the explicitly martial rhetoric adopted by China and Philippines is a means of mobilising (civilian) society in the COVID-19 response. It is too easy to hand-wave this as the decision of a sovereign nation: politically foregrounding the role of the military clashes with key international CMCoord principles, including the use of international military assets as one of 'last resort', and any response should maintain unambiguous civilian leadership. Although CMCoord guiding documents apply these principles to the use of international military and civil defence assets, in practice, many humanitarian practitioners consider them to be either applicable or key points of reference in guiding humanitarian organisations' engagements with domestic armed actors as well. This was evidenced, for example, by the Philippines Humanitarian Country Team context-specific guidance for COVID-19, which applied international CMCoord principles to humanitarians' interactions with the AFP.

The need for disaggregation between 'military', police, and gendarme

Most literature and guidance tends to refer collectively to 'militaries', which obscures important distinctions that different security and armed actors play in the midst of public health emergencies. ${ }^{5}$ These related actors can be categorised in a number of different ways. Of fundamental importance is to maintain, in discussion and analysis, differentiation between international and domestic militaries. In some instances of military contribution to the COVID-19 crisis, such as China's multiple military support missions to allied governments, an international military provides assistance beyond their national borders at the request of and with the permission of a host nation. In other instances, this support occurs domestically, which represents a fundamentally different conceptual and legal question, especially when considering how to balance sovereign decisions that counter civil-military guiding documents.

Further, within any specific military, different branches or departments may have very different cultures, doctrinal approaches to emergency response, capabilities, and ways of operating. For example, military medical services are often quite distinct from combat engineers or an artillery brigade and can often be deployed independently. ${ }^{12}$ And critically, a military's medical and public health capabilities, as distinct from other capabilities, require distinct consideration in pandemic contexts.

It is particularly crucial to differentiate between militaries and police, gendarme, and paramilitary forces, as well as, in some contexts, non-state armed groups. Where they exist, each of these groups has contributed to the COVID-19 response. They are, however, frequently grouped into one conceptual space in the literature, despite the fact that these groups are neither military, nor necessarily armed.

In China, for example, the militia played a prominent role in carrying out massive community-engagement efforts at scale, and therein filled an important role within the overall COVID-19 response. Here, the militia functioned as a distinct actor-type compared to active and reserve forces. In the Philippines, the national police and the military both have served a 'law-and-order' function, including monitoring checkpoints and curfew compliance, and there has not been a sharp distinction between the two, in terms of their overlapping functions, as well as how they appear (police have warn military-style camouflage uniforms even when operating in urban environments). ${ }^{89}$ The UK offers an interesting and important counterexample to the Chinese and Philippines case studies: the police and militaries are deliberately and obviously highly separate institutions. In most cases, police officers are unarmed, for example, and there is no gendarme to 'bridge' the police and military domains. While the military was widely involved in supporting the COVID-19 response, to date, it has never been involved in ensuring or enforcing public order, and military personnel enjoy fewer legal protections than their civilian security counterparts. Perhaps this results in a higher degree of acceptance by the general public within a liberal democracy, as the military role is more clearly understood as deployed uniquely in response to a specific emergency, though this requires further qualitative evaluation.

What these case studies consistently evidence is that-aside from the importance of ensuring this level of disaggregation is afforded proper attention in analysis of humanitarian $\mathrm{CME}$-the broader country and regional context in which police, military, and 'militarised police' are operating must also be considered. As they sit somewhere between civilian and military, the latter may create particular risks in some contexts as popular perception may not maintain this admittedly confused distinction. For example, civilian populations in complex emergencies may be far less receptive to gendarme carrying out support functions than populations in consistently stable contexts, as they are rightfully more sceptical of underlying motives and safety (e.g. Oppenheim et al.). ${ }^{90}$

These observations underscore that military and police operate as complementary stakeholders in an escalated spectrum of responses that occur in pandemics, as well as across a wide range of humanitarian operations. While the literature has traditionally explored each respective actor-type's relations with civilian counterparts in isolation, such analysis should be better joined up to build a better holistic understanding of security actor's roles in a pandemic response ecosystem as a whole.

Pandemics as a unique crisis domain and 'stress test' the civilian international system

While the preceding points are illustrated case study observations related to COVID-19, they highlight concepts and issues that have long remained underaddressed in the broader debate, discussion, and literature around humanitarian CME.

There are, however, a number of distinct factors in how militaries and civilians interact in the context of epidemics. ${ }^{5}$ In most disease outbreak contexts, the WHO draw on their World Health Emergencies Programme (HEP) rosters, relying on deployments of an international experts. Yet the pandemic nature of COVID-19 highlights a fundamental flaw in this structure: as the crisis drew these experts back into their domestic contexts, this resource-a core component of the international architecture developed to respond to disease outbreaks-was unavailable at precisely the time it was needed most. Countries throughout the world have thus fallen back to their domestic capacities and resilience at hand, which frequently meant a turn to military resources. This observation has

Page $9 / 16$ 
profound implications for future CME and response. First, it calls for more direct engagement with health emergencies in existing CMCoord guidance. This realm has not been entirely neglected. For example, context-specific guidance has been produced, including global guidelines for COVID-19 produced by the United Nations Civil-Military Coordination Service. ${ }^{5}$ However, the issues identified throughout this section suggest a wider array of challenges worthy of greater attention, within the broader context of a fundamental re-evaluation of domestic disaster response frameworks in the wake of COVID-19.

Further, the pandemic demands consideration of an unresolved but fundamental question: is the scale of this crisis unique, or-as global megatrends like climate change, urbanisation, globalisation, and protracted crises and displacement occur-can and should countries and the international community anticipate more instances of future 'global mega-crises' which overwhelm international response architectures once again? Countries that have found their own domestic civilian resiliency to be lacking during COVID-19 will need to address these capacity constraints in the immediate, medium, and long term.

The role of the military will undoubtably be central to any such conversation, regardless of context but especially in the Global South, where domestic civilian capacities (and resources for further developing them) are lacking. Further, given the strong professional overlaps in and alignment between military medical and civilian health sectors, CME during health emergencies and pandemics may even represent comparatively fruitful spaces for fostering this domestic capacity around shared health priorities. ${ }^{12}$ Therein, COVID-19 is a clear wake-up call to the need for better recognising CME as a priority issue for future public health emergencies and can no longer remain an academic after-thought or policy post-script.

\section{Conclusions}

The preceding discussion has important implications for both research and policy on humanitarian CME. First, this paper suggests the need for research and analysis on this topic to better consider major health emergencies as a specific type of complex humanitarian crisis, with distinct implications for developing appropriate, tailored good practice. This priority can be supported by expanding comparative analysis of military involvement in COVID-19 responses in additional countries to contribute to further CME lessons-learning in the context of pandemics.

Second, particularly in the context of future global mega-crises and health emergencies in which international humanitarian response architecture and norms (in their current form) are overwhelmed, it is likely that militaries will play an increasing role in supporting domestic, regional, and even international resilience. Our case studies suggest that nations will increasingly deploy military assets as first response. Existing CMCoord guidance does not address the particular complexities for humanitarian organisations of operating in such environments. As this paper has noted, CMCoord guidance focuses on the use of international MCDA in humanitarian response. In contexts where there is robust civilian governmental leadership and extensive domestic military involvement, in what ways can and should local and international humanitarian organisations interact with these response structures while still retaining the civilian, principled nature of their own operations? This question deserves more attention and analysis.

This point, in turn, offers an imperative to reconceptualise mechanisms for effective CME. Decision-makers should review existing international civil-military guiding documents with a view to addressing these points and creating specific guidance for health emergencies including pandemics and epidemics. They should assume militaries will be a central stakeholder during resilience planning for future global mega-crises and health emergencies on the basis of these capabilities and capacities, with rigorous consideration for any risks and consequences that may result. Distinct capabilities and capacities of militaries in response to these mega-crises and health emergencies must be clearly identified and inventoried. And 'military actors' should also be disaggregated between domestic and international, as well as between military and other non-military armed groups and security actors.

The gravity of the challenges faced in CME during COVID-19 explored in this article, as well as the likelihood of future epidemics or pandemics impacting a globalised planet, suggest the importance of pushing this research, policy, and guidance forward. Over the past hundred-or-so years, the world has confronted multiple outbreaks of coronaviruses, Ebola, and influenza, and even as the COVID-19 pandemic persists, global leaders have begun preparing for the next pandemic. ${ }^{92}$ Working toward more effective management of CME during large-scale disease outbreaks-and indeed, building an evidence base of practices to manage and surmount key challenges-should be a key component of these efforts.

The case studies presented in this article, and the analysis and recommendations offered, aim to contribute to this broader effort. The observations drawn from these illustrative examples are necessarily limited in generalizability, but nonetheless raise several important issues and questions that are timely for the immediate lessons-learning process to follow COVID-19 in the coming years. Additional case study research, illustrating the richness of a truly global diversity of country experiences in domestic CME during their own COVID-19 responses, can provide welcome further context. Such empirical detail will become more available as the post-factor evidence-base surrounding the pandemic continues to emerge, and its analysis can ultimately inform operational insights to guide domestic and international civil-military coordination ahead of future potential pandemics and other global mega-crises.

\section{Abbreviations}




\begin{tabular}{|c|c|}
\hline Acronym & Definition \\
\hline AFP & Armed Forces of the Philippines \\
\hline $\mathrm{CMC}$ & Central Military Commission \\
\hline CMCoord & Humanitarian civil-military coordination \\
\hline CME & Civil-military engagement \\
\hline CPP & Communist Party of the Philippines \\
\hline CSF & COVID-19 Support Force \\
\hline Dstl & Defence Science and Technology Laboratory \\
\hline HEP & Health Emergencies Programme \\
\hline IASC & Inter-Agency Standing Committee \\
\hline IATF-EID & Inter-Agency Technical Working Group for the Management of Emerging Infectious Diseases \\
\hline MACA & Military Aid to Civil Authorities \\
\hline MCDA & Military and Civil Defence Assets \\
\hline MoD & Ministry of Defence \\
\hline NDRRMC & Secretariat of the National Disaster Risk Reduction and Management Council \\
\hline NHS & National Health Service \\
\hline NTP & COVID-19 National Task Force \\
\hline PCC & Party Central Committee \\
\hline PHE & Public Health England \\
\hline PLA & People's Liberation Army \\
\hline PLA-JLSF & People's Liberation Army Joint Logistics Support Force \\
\hline PNP & Philippine National Police \\
\hline PPE & Personal protective equipment \\
\hline UK & United Kingdom \\
\hline UN OCHA & United Nations Office for the Coordination of Humanitarian Affairs \\
\hline WFP & World Food Programme \\
\hline WHO & World Health Organisation \\
\hline
\end{tabular}

\section{Declarations}

\section{Ethics approval and consent to participate}

Not applicable.

\section{Consent for publication}

Not applicable.

\section{Availability of data and material}

Not applicable.

\section{Competing interests}

There is competing interest to declare.

\section{Funding}

There is no funding to declare. 


\section{Authors' contributions}

All authors contributed substantially and equally to this manuscript throughout, including its: conception; design; analysis; interpretation of the data; drafting; and substantial revisions. All authors have approved the submitted version and have agreed both to be personally accountable for the author's own contributions and to ensure that questions related to the accuracy or integrity of any part of the work, even ones in which the author was not personally involved, are appropriately investigated, resolved, and the resolution documented in the literature.

\section{Acknowledgements}

We would like to thank Mr. Michael Marx of the United Nations Office for the Coordination of Humanitarian Affairs (OCHA)'s Civil-Military Coordination Service, Mr. Dave Polatty of the U.S. Naval War College Humanitarian Response Program, and Dr. Adam Levine of the Center for Human Rights and Humanitarian Studies at Brown University's Watson Institute for International and Public Affairs for their invaluable support in the development of this paper at every stage.

\section{References}

1. Presidential News Desk. Guidance of President Rodrigo Roa Duterte During the Inter-Agency Task Force Meeting on the Coronavirus Disease 2019 (COVID-19), https://pcoo.gov.ph/wp-content/uploads/2020/03/20200316-Guidance-of-President-Rodrigo-Roa-Duterte-on-the-Coronavirus-Disease-2019COVID-19.pdf (2020, accessed 1 April 2021).

2. Jones CL. The Chinese Communist Party's 'People's War' on COVID-19. RealClearDefense, 8 April 2020, https://www.realcleardefense.com/articles/2020/04/08/the_chinese_communist_partys_peoples_war_on_covid-19_115184-full.html (8 April 2020, accessed 1 April 2021).

3. Oprysko C, Luthi S. Trump labels himself 'a wartime president' combating coronavirus. POLITICO, 18 March 2020, https://www.politico.com/news/2020/03/18/trump-administration-self-swab-coronavirus-tests-135590 (18 March 2020, accessed 1 April 2021).

4. Plana S, Vershuren S. War Isn't (Quite) the Right Metaphor for COVID-19. Political Violence at a Glance, https://politicalviolenceataglance.org/2020/05/20/war-isnt-quite-the-right-metaphor-for-covid-19/ (2020, accessed 1 April 2021).

5. Boland ST, Mclnnes C, Gordon S, et al. Civil-military relations: a review of major guidelines and their relevance during public health emergencies. BMJ Mil Health. Epub ahead of print 4 August 2020. DOI: 10.1136/bmjmilitary-2020-001505.

6. Metcalfe V, Haysom S, Gordon S. Trends and challenges in humanitarian civil-military coordination: A review of the literature: HPG Working Paper. Working Paper, London: Overseas Development Institute, https://www.slideshare.net/AnthonyRichard4/humanitarian-civilmilitary-coordination (May 2012, accessed 11 December 2019).

7. Colona S. Humanitarian Principles: A Bridge and a Compass for Civil-Military Coordination. In: A Civil-Military Response to Hybrid Threats. 2017, pp. $123-143$.

8. Kaplan J, Easton-Calabria E. Military medical innovation and the Ebola response: a unique space for humanitarian civil-military engagement. Humanitarian Practice Network, https://odihpn.org/magazine/military-medical-innovation-and-the-ebola-response-a-unique-space-for-humanitarian-civilmilitary-engagement/ (June 2015, accessed 22 March 2021).

9. Grace R. Surmounting Contemporary Challenges to Humanitarian-Military Relations_Grace.pdf. Center for Human Rights and Humanitarian Studies at the Watson Institute for International and Public Affairs, Brown University, https://watson.brown.edu/chrhs/files/chrhs/imce/research/Surmounting\%20Contemporary\%20Challenges\%20to\%20HumanitarianMilitary\%20Relations_Grace.pdf (August 2020, accessed 1 April 2021).

10. Bollettino V, Anders B. Civil-Military Coordination: A Framework for Measuring Effectiveness in Humanitarian Response. Journal of Humanitarian Affairs 2020; 2: 3-10.

11. Kwaja CMA, Olivieri DJ, Samuel T. Boland, et al. Civilian perception of the role of the military in Nigeria's 2014 Ebola outbreak and health-related responses in the North East region. BMJ Mil Health. Epub ahead of print 5 February 2021. DOI: 10.1136/bmjmilitary-2020-001696.

12. Horne S, Boland S. Understanding medical civil-military relationships within the humanitarian-development-peace 'triple nexus': a typology to enable effective discourse. BMJ Mil Health. Epub ahead of print 6 March 2020. DOI: 10.1136/jramc-2019-001382.

13. Dunlap C. The Police-ization of the Military. Journal of Political \& Military Sociology 1999; 27: 217-232.

14. Rothstein M. From SARS to Ebola: Legal and Ethical Considerations for Modern Quarantine. Indiana Health Law Review 2015; $12: 227$.

15. Kalkman JP. Military crisis responses to COVID-19. Journal of Contingencies and Crisis Management 2020; 29: 99-103.

16. Gad M, Kazibwe J, Quirk E, et al. Civil-military cooperation in the early response to the COVID-19 pandemic in six European countries. BMJ Mil Health 2021; 167: 234-243.

Page $12 / 16$ 
17. Gibson-Fall F. Military responses to COVID-19, emerging trends in global civil-military engagements. Review of International Studies 2021; 47: 155-170.

18. Eric Chewning, David Chinn, Elizabeth Young McNalty, et al. Lessons from the military for CoVID-time leadership. McKinsey,

http://ceros.mckinsey.com/coronavirus-promo-video-desktop (20 May 2020, accessed 1 April 2021).

19. Koop O, Polimac D, Carey L, et al. Military Personnel and COVID-19: An Exploratory Scoping Review. Report, La Trobe. Epub ahead of print 4 December 2020. DOI: $10.26181 / 5 \mathrm{fbc73d} 41425 \mathrm{c}$.

20. Tetteh HA. A Leader's Guide to Crisis Communication: Lessons from Ebola for COVID-19. Mil Med 2020; 185: e1371-e1375.

21. NATO. Coronavirus response: NATO Allies deploy military medics to the Czech Republic. NATO, http://www.nato.int/cps/en/natohq/news_179458.htm (2020, accessed 1 April 2021).

22. Wang C, Horby PW, Hayden FG, et al. A novel coronavirus outbreak of global health concern. The Lancet 2020; 395: 470-473.

23. Kania E, Lasakai L. Myths and Realities of China's Military-Civil Fusion Strategy. Center for a New American Security,

https://www.cnas.org/publications/reports/myths-and-realities-of-chinas-military-civil-fusion-strategy (28 January 2021, accessed 22 March 2021).

24. Wang Y. China's Covid Success Story is Also a Human Rights Tragedy. Human Rights Watch, https://www.hrw.org/news/2021/01/26/chinas-covidsuccess-story-also-human-rights-tragedy (26 January 2021, accessed 1 April 2021).

25. Kania E, McCaslin IB. People's Warfare against COVID-19: Testing China's Military Medical and Defense Mobilization Capabilities. Institute for the Study of War, http://www.understandingwar.org/people\%E2\%80\%99s-warfare-against-covid-19 (December 2020, accessed 22 March 2021).

26. Lewis D. China's coronavirus vaccine shows military's growing role in medical research. Nature 2020; 585: $494-495$.

27. CPC CP of C. National Defense Mobilization Law of the People's Republic of China [Effective], http://eng.mod.gov.cn/publications/2017-

03/03/content_4774223.htm (2010, accessed 22 March 2021).

28. Fighting COVID-19: China in Action, http://www.xinhuanet.com/english/2020-06/07/c_139120424.htm (2020, accessed 22 March 2021).

29. Guoshun L, Ren Z. The nation's moving charge is ahead of the 'epidemic' in the national war! The national defense mobilization system actively participates in winning the battle against epidemic prevention and control. Defence Times Pioneer, 2 November 2020, www.sohu.com/a/372187264_594189 (2 November 2020, accessed 22 March 2021).

30. Luce L, Richter E. Handling Logistics in a Reformed PLA: The Long March Toward Joint Logistics. In: Chairman Xi Remakes the PLA. Washington D.C., https://ndupress.ndu.edu/Media/News/News-Article-View/Article/1748004/handling-logistics-in-a-reformed-pla-the-long-march-toward-joint-logistics/ (2019).

31. Chan M. China sends fresh military medical crews to coronavirus-hit Wuhan. South China Morning Post, 13 February 2020,

https://www.scmp.com/news/china/diplomacy/article/3050520/chinese-military-sends-fresh-medical-crews-coronavirus-hit (13 February 2020 , accessed 22 March 2021).

32. Wu W. Coronavirus hospital set to open in Wuhan with 1,400 military medical staff. South China Morning Post, 2 February 2020,

https://www.scmp.com/news/china/politics/article/3048592/coronavirus-hospital-set-open-wuhan-1400-military-medical-staff (2 February 2020, accessed 22 March 2021).

33. Wuthnow J. Responding to the Epidemic in Wuhan: Insights into Chinese Military Logistics. 20 Issue 7, The Jamestown Foundation, https://jamestown.org/program/responding-to-the-epidemic-in-wuhan-insights-into-chinese-military-logistics/ (13 April 2020, accessed 22 March 2021).

34. Department of Global Communications. Supply Chain and COVID-19: UN rushes to move vital equipment to frontlines. United Nations COVID-19 Response, https://www.un.org/en/coronavirus/supply-chain-and-covid-19-un-rushes-move-vital-equipment-frontlines (2020, accessed 14 April 2021).

35. Chen F. The circle of friends mobilized by science and technology is getting bigger and bigger. China National Defense News, 10 April 2020 , http://www.mod.gov.cn/mobilization/2020-04/10/content_4863411.htm (10 April 2020, accessed 22 March 2021).

36. Heyun Z. National defense mobilization system: gather all people's forces to fight the epidemic with one heart, http://www.xinhuanet.com/mil/202002/26/c_1210490583.htm (2020, accessed 22 March 2021).

37. Jinping $X$. To study the work of responding to the novel coronavirus pneumonia epidemic, http://www.gov.cn/xinwen/2020-

02/15/content_5479271.htm (2020, accessed 22 March 2021).

38. Chan M, Zheng W. Meet the major general on China's coronavirus scientific front line. South China Morning Post, 3 March 2020, https://www.scmp.com/news/china/military/article/3064677/meet-major-general-chinas-coronavirus-scientific-front-line (3 March 2020, accessed 22 March 2021).

39. Zhuo C. Chinese military medical experts help with Sierra Leone's COVID-19 fight - China Military. Xinhua News Agency, 27 August 2020 , http://eng.chinamil.com.cn/view/2020-08/27/content_9891523.htm (27 August 2020, accessed 1 April 2021).

Page $13 / 16$ 
40. UK MoD. 200 UK troops deploy to support flood relief. GOV.UK, https://www.gov.uk/government/news/200-uk-troops-deploy-to-support-flood-relief (2019, accessed 8 March 2021).

41. Coronavirus: British Evacuees Arrive At RAF Base Before Entering Quarantine. Forces Network, 1 February 2020,

https://www.forces.net/news/coronavirus-plane-carrying-british-evacuees-lands-raf-brize-norton (1 February 2020, accessed 1 February 2020).

42. UK MoD. Military Aid to Civil Authorities: The COVID Support Force. Medium, https://medium.com/voices-of-the-armed-forces/military-aid-to-civilauthorities-the-covid-support-force-acd80ec70099 (2020, accessed 8 March 2021).

43. UK MoD. COVID Support Force: the MOD's continued contribution to the coronavirus response. GOV.UK, https://www.gov.uk/guidance/covid-supportforce-the-mods-continued-contribution-to-the-coronavirus-response (2021, accessed 8 March 2021).

44. COVID Response Becomes Military's 'Biggest Homeland Operation In Peacetime'. Forces Network, 4 January 2021, https://www.forces.net/news/covidresponse-militarys-biggest-homeland-operation-peacetime (4 January 2021, accessed 8 March 2021).

45. UK Government. Emergency Powers Act 1964, https://www.legislation.gov.uk/ukpga/1964/38 (1964, accessed 8 March 2021).

46. Feldman D. English Public Law. Oxford University Press, 2009.

47. Bowley DM, Davis N, Ballard M, et al. Military assistance to the civil authority: medical liaison with the Manchester clinicians after the Arena bombing. BMJ Mil Health 2020; 166: 76-79.

48. British Red Cross and Chatham House. Civil-Military Relations: A Focus on Health Emergencies and Epidemics. London: British Red Cross and Chatham House, https://www.redcross.org.uk/about-us/what-we-do/international/humanitarian-policy (17 July 2018, accessed 8 March 2021).

49. Dstl UDS and TL. Dstl Scientists are helping to conquer the spread of COVID-19. GOV.UK, https://www.gov.uk/government/news/dstl-scientists-arehelping-to-conquer-the-spread-of-covid-19 (2020, accessed 8 March 2021).

50. Military Support NHS By 3D Printing PPE. Forces Network, 21 April 2020, https://www.forces.net/news/military-support-nhs-3d-printing-ppe (21 April 2020, accessed 8 March 2021).

51. Coronavirus: NHS contact-tracing app is tested at RAF base. BBC News, 22 April 2020, https://www.bbc.com/news/technology-52381103 (22 April 2020, accessed 8 March 2021).

52. Watts G, Wilkinson E. What the NHS is learning from the British army in the covid-19 crisis. BMJ 2020; $369:$ m2055.

53. Chambers K. Coronavirus: Military Personnel Train To Drive Oxygen Tankers As Lockdown Begins. Forces Network, 24 March 2020 ,

https://www.forces.net/news/coronavirus-military-personnel-train-drive-oxygen-tankers-lockdown-begins (24 March 2020, accessed 8 March 2021).

54. Covid: Army deployed to drive ambulances in Wales. BBC News, 22 December 2020, https://www.bbc.com/news/uk-wales-55410775 (22 December 2020, accessed 8 March 2021).

55. Wallace B. Record number of armed forces personnel help with Covid response. GOV.UK, https://www.gov.uk/government/news/record-number-ofarmed-forces-personnel-help-with-covid-response (2021, accessed 8 March 2021).

56. ARRC. NATO Allied Rapid Reaction Corps Staff deploy to London to help combat COVID-19, https://shape.nato.int/news-archive/2020/video-natoallied-rapid-reaction-corps-staff-deploy-to-london-to-help-combat-covid19.aspx (2020, accessed 8 March 2021).

57. UK MoD. 350 additional military personnel deployed in Scottish Covid response, https://www.army.mod.uk/news-and-events/news/2021/02/350plusmilitary-personnel-forscottish-covid-response/ (2021, accessed 8 March 2021).

58. Thornton R. What Covid-19 reveals about the UK's capacity to deal with the changing character of warfare. King's College London, https://www.kcl.ac.uk/covid-19-and-why-state-resilience-in-the-united-kingdom-needs-to-be-strengthened-the-link-to-the-changing-character-of-war-and-lessonsfrom-russia (2020, accessed 14 April 2021).

59. Broadshare And Rescript: What Are The UK's Coronavirus Military Operations? Forces Network, 11 January 2021, https://www.forces.net/news/broadshare-and-rescript-what-are-uks-coronavirus-military-operations (11 January 2021, accessed 8 March 2021).

60. Lasco G. Medical populism and the COVID-19 pandemic. Global Public Health 2020; 15: 1417-1429.

61. Aguilar FVJr. Preparedness, Agility, and the Philippine Response to the Covid-19 Pandemic The Early Phase in Comparative Southeast Asian Perspective. Philippine Studies: Historical and Ethnographic Viewpoints 2020; 68: 373-421.

62. Republic Act No. 11469, http://legacy.senate.gov.ph/Bayanihan-to-Heal-as-One-Act-RA-11469.pdf (2020, accessed 22 March 2021).

63. Sadongdong M. Lorenzana heads COVID-19 national task force. Manila Bulletin, 25 March 2020, https://mb.com.ph/2020/03/25/lorenzana-headscovid-19-national-task-force/ (25 March 2020, accessed 22 March 2021).

Page $14 / 16$ 
64. Proclamation No. 922, https://covidlawlab.org/wp-content/uploads/2020/10/Proclamation-No.-922.pdf (2020, accessed 22 March 2021).

65. Proclamation No. 929, https://www.officialgazette.gov.ph/downloads/2020/03mar/20200316-PROC-929-RRD.pdf (2020, accessed 22 March 2021).

66. HAG HAG. Humanitarian Civil-Military Coordination in Emergencies: Towards a Predictable Model, https://humanitarianadvisorygroup.org/wpcontent/uploads/2021/01/RCG_Towards-a-predictable-model_2nd-ed_Final_electronic.pdf (2020, accessed 22 March 2021).

67. Republic Act No. 11479, https://www.officialgazette.gov.ph/downloads/2020/06jun/20200703-RA-11479-RRD.pdf (2019, accessed 22 March 2021).

68. Ratcliffe R. Duterte's anti-terror law a dark new chapter for Philippines, experts warn. The Guardian, 9 July 2020,

http://www.theguardian.com/world/2020/jul/09/dutertes-anti-terror-law-a-dark-new-chapter-for-philippines-experts-warn (9 July 2020, accessed 22 March 2021).

69. Nepomuceno P. AFP plays key role in gov't Covid-19 response: Gapay. Philippine News Agency, 31 December 2020,

https://www.pna.gov.ph/articles/1126037 (31 December 2020, accessed 22 March 2021).

70. Nepomuceno P. Over $1 \mathrm{M}$ pounds of med supplies in Covid-19 fight transported: AFP. Philippine News Agency, 6 May 2020,

https://www.pna.gov.ph/articles/1102041 (6 May 2020, accessed 22 March 2021).

71. Semilla N. Hard lockdown starts in Cebu City. Philippine Daily Inquirer, 25 June 2020, https://newsinfo.inquirer.net/1296999/hard-lockdown-starts-incebu-city (25 June 2020, accessed 22 March 2021).

72. Santos AP. Ghost town: Manila under coronavirus lockdown. Al Jazeera English, 15 March 2020, https://www.aljazeera.com/news/2020/3/15/ghosttown-manila-under-coronavirus-lockdown (15 March 2020, accessed 22 March 2021).

73. Mercado L. Ideas for a Pro-Poor and Pro-Women Approach to COVID-19. Oxfam in Asia, https://asia.oxfam.org/latest/blogs/ideas-pro-poor-and-prowomen-approach-covid-19 (2020, accessed 22 March 2021).

74. Philippines: Curfew Violators Abused. Human Rights Watch, 26 March 2020, https://www.hrw.org/news/2020/03/26/philippines-curfew-violatorsabused (26 March 2020, accessed 22 March 2021).

75. 'Toxic lockdown culture' of repressive coronavirus measures hits most vulnerable. UN News, 27 April 2020, https://news.un.org/en/story/2020/04/1062632 (27 April 2020, accessed 22 March 2021).

76. Mangosing F. Lorenzana, chief enforcer of anti-COVID-19 national plan, calls for full AFP, PNP support. Philippine Daily Inquirer, 26 March 2020, https://newsinfo.inquirer.net/1248973/lorenzana-chief-enforcer-of-anti-covid-19-national-plan-calls-for-full-afp-pnp-support (26 March 2020 , accessed 22 March 2021).

77. Who are the ex-generals leading the President's COVID-19 response plan? ABS-CBN News, 31 July 2020, https://news.abscbn.com/news/07/31/20/who-are-the-ex-generals-leading-the-presidents-covid-19-response-plan (31 July 2020, accessed 22 March 2021).

78. Cagula KE. Groups hit PH military-led action plan vs coronavirus. Davao Today, http://davaotoday.com/main/politics/groups-hit-ph-military-led-actionplan-vs-coronavirus/ (2020, accessed 22 March 2021).

79. HCT PHAT. Philippines HCT Operational Guidance on Providing Assistance in the Context of COVID-19 Response Operations, https://reliefweb.int/sites/reliefweb.int/files/resources/200407\%20Philippines\%20HCT\%200perational\%20Guidance\%20on\%20Providing\%20Assistance\%20fc 19.pdf (2020, accessed 22 March 2021).

80. Gowan R. What's Happened to the UN Secretary-General's COVID-19 Ceasefire Call? International Crisis Group,

https://www.crisisgroup.org/global/whats-happened-un-secretary-generals-covid-19-ceasefire-call (2020, accessed 22 March 2021).

81. CPP CP of the P. Ceasefire Order: $00.00 \mathrm{H}$ of 26 March 2020 to $23.59 \mathrm{H}$ of 15 April 2020. Philippine Revolution Web Central, https://cpp.ph/statement/ceasefire-order-00-00h-of-26-march-2020-to-23-59h-of-15-april-2020/ (2020, accessed 22 March 2021).

82. Protecting the most vulnerable families in Mindanao from COVID-19. UNHCR Philippines, 7 May 2020, https://www.unhcr.org/ph/18507-apr2020enews-mindanao.html (7 May 2020, accessed 22 March 2021).

83. Singh J, Jani MH. COVID-19 and Terrorism in the Southern Philippines: More Trouble Ahead. The Diplomat, 26 August 2020 , https://thediplomat.com/2020/08/covid-19-and-terrorism-in-the-southern-philippines-more-trouble-ahead/ (26 August 2020, accessed 22 March 2021).

84. Abo N, Ayao A. Violence or the virus? Mindanao's displaced forced to choose, https://www.thenewhumanitarian.org/opinion/2020/06/01/PhilippinesMindanao-coronavirus-violence-women-girls (2020, accessed 22 March 2021).

85. Duffield M. Risk-Management and the Fortified Aid Compound: Everyday Life in Post-Interventionary Society. Journal of Intervention and Statebuilding 2010; 4: 453-474. 
86. UN OCHA. Foreign Military and Civil Defence Assets in Support of Humanitarian Emergency Operations: What is Last Resort?, https://www.unocha.org/sites/dms/Documents/Last\%20Resort\%20Pamphlet\%20-\%20FINAL\%20April\%202012.pdf (2012).

87. Mai J. US rivalry will foster our political instability: China security chief. South China Morning Post, 13 November 2020,

https://www.scmp.com/news/china/diplomacy/article/3109762/our-tense-rivalry-us-will-foster-political-volatility-china (13 November 2020, accessed 22 March 2021).

88. Xiaotian Z, Zhidong X, Weiping Z. Overview of international military conflicts and security situation in 2020. China Military Online, 24 December 2020, http://eng.chinamil.com.cn/view/2020-12/24/content_9957863.htm (24 December 2020, accessed 22 March 2021).

89. Fianza F. The camouflage uniforms. Manila Standard, https://manilastandard.net/mobile/article/346713 (2021, accessed 1 April 2021).

90. Oppenheim B, Lidow N, Ayscue P, et al. Knowledge and beliefs about Ebola virus in a conflict-affected area: early evidence from the North Kivu outbreak. J Glob Health; 9. Epub ahead of print 2019. DOI: 10.7189/jogh.09.020311.

91. Singer BJ, Thompson RN, Bonsall MB. The effect of the definition of 'pandemic' on quantitative assessments of infectious disease outbreak risk. Sci Rep 2021; 11: 2547.

92. Erlanger S. World leaders call for an international treaty to combat future pandemics. The New York Times, 30 March 2021, https://www.nytimes.com/2021/03/30/world/europe/world-health-treaty-pandemics.html (30 March 2021, accessed 1 April 2021). 